\title{
FUN BILINGUAL-BIMODAL EBOOKS FOR DEAF CHILDREN: DEVELOPING LANGUAGE AND PRELITERACY SKILLS
}

\author{
EBOOKS BIMODAIS DIVERTIDOS PARA CRIANÇAS SURDAS: DESENVOLVENDO \\ A LINGUAGEM E HABILIDADES DE PRÉ-ALFABETIZAÇÃO
}

\begin{abstract}
DIVERTIDOS LIBROS ELECTRÓNICOS BIMODALES BILÍNGÜES PARA NIÑOS SORDOS: DESARROLLANDO LA LENGUA Y LA HABILIDAD DE PRE-ESCRITA
\end{abstract}

\author{
Donna Jo Napoli* \\ Eugene R. Mirus ${ }^{* *}$
}

\begin{abstract}
Ebooks provide new ways to advance developing literacy among deaf children. While some aim to promote literacy through explicit pedagogical techniques, the new ebooks described here aim only to offer stories that are fun to share, encouraging learning through interaction that naturally fosters language and preliteracy skills. Reading for pleasure is recognized as valuable for hearing children; it needs to be recognized as such for deaf children. We present the rationale for these ebooks and give examples of how they advance preliteracy skills, in the hopes that those raising and educating deaf children will use them, offered gratis on the Internet.
\end{abstract}

Keywords: deaf children, literacy, ebooks, shared reading activities

\section{Introduction}

This paper describes ebooks of a new sort, which are offered gratis on the Internet. They are intended to promote language skills in deaf children, leading to overall better skills, at home and at school. Most of the attention with regard to literacy in deaf children is focused on printliteracy skills. However, these ebooks also introduce children to the mechanisms used in storytelling among the deaf, thus they promote sign-literacy skills, as well.

\footnotetext{
* Ph.D., Dept. of Linguistics, Swarthmore College, 500 College Ave., Swarthmore, PA, 19081, USA. E-mail: donnajonapoli@gmail.com

** Ph.D., Department of ASL and Deaf Studies, Gallaudet University, 800 Florida Ave, N.E., Washington, DC, 20002, USA. E-mail: gene.mirus@gmail.com
} 


\section{Background}

The new ebooks are founded on three propositions: fun is essential to learning, deaf children's academic achievements depend largely on a firm foundation in a first language, and shared reading activities (SRAs) can be fun events that help develop a first language.

First, play is a major way children learn (KUSCHNER, 2008), allowing connections critical to reading (GAMBRELL, 2011) and math (MURAYAMA, et al., 2013). It promotes health (ALEXANDER, FROHLICH, \& FUSCO, 2014), ethical development (EDMISTON, 2007), and lifelong happiness (MARTIN, 2014). Deaf preschoolers need to explore the world through play, nourishing cognitive faculties their plastic brains are primed to develop, like language (HUMPHRIES, et al., 2012).

Second, deaf children are at risk academically (EASTERBROOKS, et al., 2015), and most point to lack of a solid language foundation (LEDERBERG, SCHICK, \& SPENCER, 2013). Often deaf children are raised strictly orally; but the auditory information they receive may not provide language access. A bilingual approach has a better chance of protecting academic success since "... exposure to an accessible language is the key to developing nativelike proficiency in any language, and a solid first language foundation is also critical for the successful acquisition of a second language" (MOUNTY, PUCCI, \& HARMON, 2014, p. 334). Regardless of their speech skills, deaf children who sign do better academically (MAYBERRY, DEL GIUDICE, \& LIEBERMAN, 2011) in reading (FREEL, et al., 2011) and writing (BASHA, 2014), whether their parents are deaf or hearing (HASSANZADEH, 2012), although sociodemographic factors play a secondary role (SCOTT, 2015).

Third, we accept the conclusion of the 1985 National Academy of Education Commission on Reading: "The single most important activity for building the knowledge required for eventual success in reading is reading aloud to children" (ANDERSON, et al., 1985, p. 23). While much research before and after has focused on monolingual hearing children, the conclusion holds for multilingual (KALIA, 2007) and deaf (WILLIAMS, 2004) children, too. Thus, we interpret the 1985 conclusion to mean that shared reading activities (SRAs) are fundamental to reading in mono- and multilingual contexts whether speech is involved or not. Bilingual books in SRAs are used to enhance print literacy around the world (SEMINGSON, POLE, \& TOMMERDAHL, 2015). SRAs increase vocabulary and teach narrative skills, 
particularly when adult-child interaction involves higher level facilitative language techniques (TRIVETTE, DUNST, \& GORMAN, 2010). When adults ask open-ended questions about story comprehension then give the child time to consider and formulate an answer, the child's preparatory skills for print literacy grow (PETERS, 2015), including the ability to engage in inferencing (VAN KLEECK, 2008).Further, the benefit in SRAs lies in fun through interaction, not through explicit pedagogical behavior, that is, in simply talking about the written text (hereafter referred to simply as 'text') (WHITEHURST, \& ZEVENBERGEN, 2003).

Many promote pedagogical SRAs for deaf children, with guidelines for the parents, telling them to point to text words, fingerspell them, and sometimes even give a simple linguistic analysis of them (such as the NSF Science of Learning Center on Visual Language and Visual Learning (VL2) at Gallaudet University, which produces ebooks; see NAPOLI, \& MIRUS, 2015). Often pedagogical SRAs focus on 'dialogic reading', where the parent prompts the child's response, evaluates it, expands on it, then guides the child to repeat it (FUNG, CHOW, MCBRIDE-CHANG, 2005). Such SRAs are lessons - generally recommended for children over five.

What about younger children? SRAs are crucial for them (MOL, \& BUS, 2011) and ebooks for deaf preschoolers must hold their attention. Once the deaf child's attention strays, she is no longer "receiving" the book. A hearing child cannot decide not to hear; even if her attention strays, she is still exposed to the book. Not so for the deaf child; so fun is paramount.

For the past two decades, education scholars have shown that early cognitive work marks the emergent print literacy period (MAYER, \& TREZEK, 2015). Included in that work must be firm first language acquisition (BECK, \& OLAH, 2001) with extensive skills in vocabulary, syntax, and discourse (DICKINSON, MCCABE, \& ESSEX, 2006), allowing the child complex interactions with capable users of the language (MAYER, \& WELLS, 1996), as well as use of language to communicate with oneself, thus transforming thought into language (WATSON, 2001). The distinction between 'outside-in' and 'inside-out' information (WHITEHURST, \& LONIGAN, 1998) in acquiring literacy is well accepted. 'Outside-in' information includes language development, story structure, and conceptual knowledge - associated with comprehension, but not necessarily tied to text. 'Inside-out' information includes phonological and letter knowledge - closely tied to text. While much research in deaf print literacy concerns 'inside-out' skills and focuses on the child 5 and older, 'outside-in' skills are foundational: 
'inside-out' skills allow one to translate print into words; 'outside-in' skills allow one to understand what those words mean. Both are essential to reading, where 'outside-in' skills are "a critical step in learning to read for meaning" (WHITEHURST, \& LONIGAN, 2001, p. 14). The ebooks here aim to encourage activities that promote 'outside-in' information in that they advance knowledge of a sign language, facilitate metalinguistic development, promote understanding of narratives, and introduce cultural knowledge necessary for understanding texts. For example, a Christmas story informs about Santa Claus and his reindeer, putting the child in a better position to read texts about Christmas traditions.

We conclude that SRAs develop skills necessary for print literacy through extensive playful language interaction (DECKNER, ADAMSON, \& BAKEMAN, 2006). Even for older children, the key to improved reading is the joy of getting lost in a narrative or being thrilled by discovery in nonfiction. That's what makes the hard job of learning to read worth it (WILLINGHAM, 2015, p. 182). But hearing parents do not often engage in SRAs with their deaf children (EWOLDT, 1986) and, if they do, it's typically not a pleasurable experience (SCHLEPER, 1995). This needs to change.

\section{SRAs for deaf children}

Our areas of expertise led us to try to contribute toward the language development and education of deaf children by providing materials for fun SRAs. We are linguists; one of us writes children's books; one of us is a former actor in the National Theater of the Deaf, being a deaf native signer of ASL. With our students, we produce bilingual-bimodal ebooks for SRAs. The ebooks have illustrations and text, plus videos in a sign language. Ebooks with a sign narrator have been shown to increase the amount of time that families with deaf children spend in SRAs, a nontrivial result since longer exposure positively impacts language and print literacy development (MUELLER, \& HURTIG, 2010). Most of our ebooks are English/ASL; others are English/ IrishSL, Korean/KSL, Brazilian Portuguese/ Libras, Nepali/ NSL, and English/ FijiSL. As of August 2015, we have produced 16, but more are in production, including Japanese/Nihon Shuwa, Greek/Greek Sign Language, and Italian/LIS.

The ebooks help with language interaction by providing good sign language models for the family, for without a common language, the deaf child will be left out. That fact needs to be 
stressed: rich manual language exchanges with their mothers, in particular, are critical to the academic success of deaf children (CALDERON, 2000). The videos in these new ebooks promote language learning through contextual cues (CHALHOUB-DEVILLE, 2003), integration of visual and linguistic information (TANENHAUS, et al., 1995), and a reliance on world knowledge (CHAMBERS, et al., 2002). Hearing family members can also use the text when learning to sign.

The language support here is somewhat similar to that in multimedia stories for multilingual hearing children, such as the books created with Fabula software and used across Europe (EDWARDS, MONAGHAN, \& KNIGHT, 2000). Fabula books are intended to support, among others, the child whose home language is a minority (often endangered) which differs from the school language (such as Welsh-English, or Basque-Spanish). The books are read on the computer, with texts in both home and school languages. Children can click on a speaker button to hear the text read in both languages. Researchers have found several advantages. First, the minority-speaking child finds support in scaffolding from reading skills (especially comprehension) in the home language to the school language. Second, the parent who speaks the minority language but doesn't read the school language can now share books with the child, and can use those books to improve their own use of the school language. Third, the majorityspeaking child, who is often monolingual, becomes more aware of language issues in general. Similar advantages have been found in America with computer-based books using audio and video (SKOUGE, RAO, \& BOISVERT, 2007). And, on point, in a study of bilingual-bimodal ebooks with a signing narrator where hearing parents were trained on how to use the ebooks with their deaf children, even parents who were noncompliant and did not undergo the parent training learned many signs purely from watching the sign narrator (MUELLER, \& HURTIG, 2010).

Finally, the ability to review the videos promotes an analytical approach to both language and story (KRENTZ, 2006). The interaction of adult and children SRAs should help develop language and understanding of characterization and narrative, and establish a love of literature.

\section{The nitty gritty: Selecting sources and making the ebooks}

We have no funding, so all books we use as a basis for producing ebooks must be in the public domain or the copyright holders must grant us their kind permission. Deaf children (and 
their parents) deserve high quality reading materials, which we hope to guarantee by using standardly published books or books offered on the Internet that our students unanimously agree upon and that we test on hearing children before deciding to go forth with them.

Within those limitations, we choose stories based on clear criteria. All must be visually rich and relatable to deaf children's life experiences, to provide a welcome into reading (DENNIS, LYNCH, \& STOCKALL, 2012). For example, a book about taking a walk at night with a father and hearing an owl hoot can create a magical feeling in a hearing child but leave a deaf child baffled. Our books deal with ordinary events like birthday parties (in KEVIN'S BIRTHDAY), as well as extraordinary but visually exciting and easily comprehensible events like a runaway baby carriage (in THE SLANT BOOK). In some a non-human character presents the story from a minority viewpoint, allowing deaf children to identify. One is about a dog who moves to a house full of cats (in ROCKY THE CAT WHO BARKS); another is about an egg that goes hard-boiled and bounces away rather than allowing himself to get cracked (in HUMPTY DUMPTY). In one a character faces huge challenges, but with self-confidence and hard work, they are met - a reassuring narrative (in THE LITTLE ENGINE THAT COULD). Some introduce classics that are part of the American heritage (such as T'WAS THE NIGHT BEFORE CHRISTMAS and JEMIMA PUDDLE DUCK). Four are nonfiction (produced with the kind permission of National Geographic), one relatable to the child's life (in HALLOWEEN), two presenting information preschoolers are generally held responsible for, metamorphosis and knowledge of African animals (in CATERPILLAR TO BUTTERFLY and in SAFARI), and one presenting just plain old fun information for any child (in RACE DAY). Most thus far target the 3 and 4 year old, but a few are for toddlers.

Once we've chosen a book, our students take over and we serve as sounding boards and guides. Half our students are at Gallaudet University and the other half, at Swarthmore College. All consult on formatting, such as whether to place the signer in a frame or surrounded by the background illustration. All have studied deaf literature and consult on how to tell the story. Gallaudet students act; our actors are deaf and signing is their primary and preferred mode of communication. Swarthmore students edit the film and do the production work. All give feedback on acting, editing, and production.

All ebooks for deaf children (not just ours) use storytelling techniques of sign literature: the 'visual vernacular' (RIGGS, 2003), thus developing sign-literacy skills in the readers. These 
techniques lack counterparts in writing, although texts can approximate: ALL CAPITALS for loudness, italics for emphasis, arrangement of letters to indicate s 1 o w action. However, visual-vernacular techniques have spoken counterparts in the form of voice alterations (GREENEBRABHAM, \& LYNCH-BROWN, 2002). Certain visual-vernacular techniques give the deaf child advantages analogous to advantages reading aloud gives the hearing child (NAPOLI, \& MIRUS, 2015). One such technique is varying motion speed (support for narrative changes). Another is varying shot distance, for example, showing a horse up close by letting the fists become the hooves, or at middle-range by letting the nondominant hand become the horse while the dominant hand is a rider on the horse, or at a distance by having the two index fingers brush past each other like horses in a race seen from the stands (help in interpreting how illustrations relate to plot). A third is role shift, whereby the signer embodies one character, then shifts (torso, head, or gaze) to embody another character (help in understanding characterization and developing Theory of Mind - see SCHICK, et al., 2007).

But there is a critical way our ebooks differ from others: we encourage our signers to read the story, let it roll around in their minds, then tell it without attempting to translate, in a way natural for them. They practice to each other and to deaf people outside class, including children. Final versions tend to integrate information from text and illustrations, and even new information that the class agrees fits (we discuss an example of this below). This kind of freedom respects the signers' creativity and has led to excellent language modeling and, we believe, more fun.

With regard to language modeling, generally sign "performers set the scene by using signs to present an essentially static image before creating moving characters" (SUTTONSPENCE, \& KANEKO, 2016, p. 168). Strict adherence to a text, in contrast, can result in grammatical but atypical signing. And we note that signing deaf parents do not feel constrained by text in SRAs with their deaf children (SWANWICK, \& WATSON, 2005), just as hearing parents don't when reading to their hearing children. The signers in our ebooks likewise are not constrained; they use accessible, uncontrived language. The acting creates visual images, then uses pauses to allow images to take hold, empowering the reader to imagine more (just as sign literature should do; RYAN, 1993). These video clips promote metalinguistic knowledge of sign languages, since the child can explore and develop knowledge of a particular sign language 
(another facet common to sign literature; BASCOM, 1965) as well as increase world knowledge and create identity (a third facet of sign literature; SUTTON-SPENCE, \& KANEKO, 2016).

With regard to fun, the relative autonomy of the signers allows them to enjoy developing their own methods, making each ebook unique, a welcome result since the complex differences in learning behaviors indicate that children should be offered reading materials which employ varying different strategies in helping decode and understand (MOORE, \& WADE, 1998).

\section{Analysis of the new ebooks}

We here describe how the new ebooks can help by offering discussion of one: TWAS THE NIGHT BEFORE CHRISTMAS: https://www.youtube.com/watch?v=42nXcSIebPE. This is representative of our ebooks for the older preschooler. Since it is a classic tale, we do not give the entire text, but simply zoom in on specific points. The signer, Caleb Joshua Smith, has

given us his permission to discuss every aspect of his work. Many of the decisions concerning how he would sign were made collaboratively with class members.

\section{Overall organization of original text and of sign rendering}

This text consists of 28 rhyming couplets. The spoken rhyme is tyrannical with respect to organization of the text. First, it ignores change of focus, as seen in this example:

He had a broad face and a little round belly, /that shook when he laughed, like a bowl full of jelly.

He was chubby and plump, a right jolly old elf,/and I laughed when I saw him, in spite of myself.

The first three lines concern the appearance of Santa; the fourth, the narrator's reaction. But rhyme forces couplets. The book designer, however, laid out the text across three pages of the original storybook:

He had a broad face

and a little round belly,

That shook when he laughed, like a bowl full of jelly. 
He was chubby and plump, a right jolly old elf,

And I laughed when I saw him,

in spite of myself.

Here the layout does not respect the couplet structure; the second page straddles two couplets. Our signer, in comparison, produced 37 video clips overall, where most clips corresponded to a page of text, but several times two clips corresponded to a page. He grouped these four lines (that is, the two couplets) above as follows, where numbers indicate the minute and second clips begin and end in the YouTube video that you can watch:

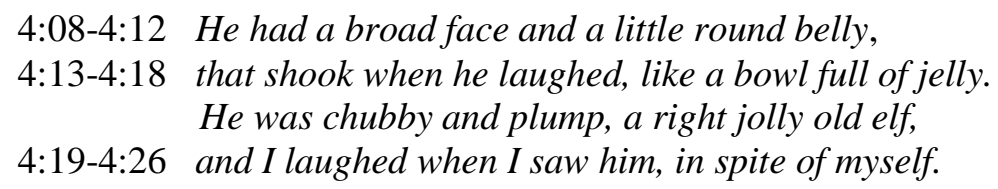

Thus there are three clips, rather than two couplets; the shift in focus from Santa to the narrator coincides with a change in clips, enhancing the child's understanding of that shift. So the signer was lockstep with the text layout - which also, appropriately, highlighted the narrative rather than the rhyme scheme. In the text, rhyme also overrides narrative shifts. For example, here are two couplets:

A wink of his eye and a twist of his head/ soon gave me to know I had nothing to dread.

He spoke not a word, but went straight to his work, /and filled all the stockings, then turned with a jerk.

Our signer, instead, presents the information in two clips this way:

4:27-4:32A wink of his eye and a twist of his head/soon gave me to know I had nothing to dread.

He spoke not a word...............

4:33-4:44 ...but went straight to his work,/and filled all the stockings, then turned with a jerk. 
The clip organization corresponds to action organization (before and after Santa begins working), rather than text rhyme organization; thus the clip organization reinforces the narrative for the child.

Finally, our signer omitted the couplet As dry leaves that before the wild hurricane fly,/when they meet with an obstacle, mount to the sky. This complex text metaphor neither clarifies nor advances the narrative. Plus the syntax is convoluted to facilitate rhyme. No one who has yet shared this ebook has complained to us about the missing couplet. It seems quite skip-able. In sum, our signer's clip organization gives consistent support to narrative understanding.

\section{The three $R$ 's as aids to literacy}

Rhyme, rhythm, and repetition can all lead to predictability, which helps the child anticipate plot and thus aids in comprehension (BIALOSTOK, 1992).

Rhyme. Spoken rhyme can help children memorize the story and associate memorized words to print (GELLER, 1983). The ability of spoken rhyme to do this depends on auditory access to rhyme. Our signers employ rhyme as well - sign rhyme. A sign can be analyzed as consisting of handshape, movement, and location (KANEKO, 2011; simplifying from the original proposal in STOKOE, 1960). In basic terms, if only one differs, we have strong rhyme; if two differ, we have weak rhyme (VALLI, 1993). For example, in the outset of this ebook, we find three sign rhymes. Here we give the couplet in English with the ASL in the first and second clips below the text:

\section{0:09-0:19 Twas the night before Christmas, when all through the house I LOOK-BACK NIGHT BEFORE CHRISTMAS HOUSE ALL-AROUND QUIET ${ }^{1}$ 0:20-0:28 Not a creature was stirring, not even a mouse. LOOK-FOR EMPTY-EVERYWHERE MOUSE LOOK-FOR NOTHING}

The signs ALL-AROUND (0:16) and EMPTY-EVERYWHERE (0.23-0.24) strongly rhyme, differing by handshape. The signs HOUSE (0:15) and QUIET (0:17-0:18) rhyme, differing only by movement

\footnotetext{
${ }^{1}$ We adopt the usual convention of using small capitals to indicate signs.
} 
and the fact that QUIET changes palm orientation. The signs MOUSE (0:25) and LOOK-FOR (0:21, repeated in 0:26) weakly rhyme, differing by location and movement, as well as by the fact that MOUSE is one-handed, while the signer uses both hands for LOOK-FOR.

Rhythm. The English poem is doggedly anapestic tetrameter (four feet per line, each foot having three beats in the pattern weak-weak-strong). But all texts, prose or poetry, tend to be read aloud with a meter (GUAÏTELLA, 1999). The perception of rhythm may be critical to gaining literacy (HUSS, et al., 2011). Thus if sign stories are to give the deaf child whatever advantage rhythm gives the hearing child in an SRA, they also must establish a rhythm. And rhythm in sign literature helps capture the attention of younger deaf children (BLONDEL, \&MILLER, 2000, 2001). Varying the size of a sign's movement path, alternating signs with different movement path lengths, and changing movement dynamics all establish rhythm (VALLI, 1993). Ways to show rhythmic closure include "resting or holding a sign after performing several in quick succession" (MALER, 2013, section 3.9), as well as "pulsing" - that is body beats while holding or repeating a sign (MALER, 2013, section 3.10).

All our signers established clear rhythms; this signer is a good example. Fingerspelling, in particular, has a strong beat, as in the rendering of these lines: And he whistled and shouted and called them by name. INow, Dasher! Now, Dancer! Now, Prancer and Vixen! IOn Comet! On, Cupid! On, Donner and Blitzen! The signer thrusts a pointing finger first to one side and fingerspells a name, then to the other side and fingerspells a name. The strong beat and body shifts - right, left - emphasize parallelism between intonational phrases and meanings.

Rhythmic phrases have end holds (pauses in which handshape and location are held steady at the end of the phrase). Looking again at the first two clips we mark the holds:

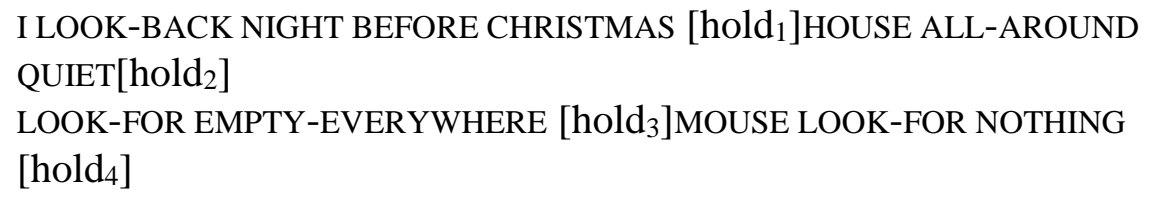

Thus these clips have an internal structure: hemistichs (each line is comprised of two parts of equal duration). The end of each hemistich is also indicated by a nonmanual marker (an articulation of something other than the hands, such as eyes, eyebrows, head, and so on). Hold 1 $(0: 14)$ and $\operatorname{hold}_{2}(0: 18)$ are accompanied by a head nod. At hold $3(0: 25)$ the eyes go from squint 
to fully open, then blink. At hold 4 (0:28) we have a blink. Holds and supporting nonmanuals mark rhythmic closures throughout the story, always coinciding with semantic groupings.

In contrast, when there is a semantic grouping that continues from one clip to the next, the signer makes these transitions obvious via articulatory means. One transition method is to repeat the sign from the end of one clip at the beginning of the next. For example, the clip corresponding to the text had just settled our brains for a long winter's nap (1:23-1:30) ends with the sign FALL-ASLEEP (1:30). The next clip (1:31-1.38) corresponds to two couplets:

When out on the roof there arose such a clatter, /I sprang from my bed to see what was the matter.

Away to the window I flew like a flash, /tore open the shutter, and threw up the sash

The signer repeats the sign FALL-ASLEEP(1:31-1:32) at the start of this clip, linking the temporal unity of the two events of falling asleep and the clatter on the roof.

The other transition method is to quickly move from the end of one clip to the beginning of the next. This happens between the clip immediately above (1:31-1:38) and the clip following, corresponding to this couplet (1:39-1:47): The moon on the breast of the new-fallen snow/ gave the lustre of midday to objects below.

Repetition. The English poem uses little repetition; the only example is seen in this one passage: Now Dasher! Now Dancer! Now Prancer and Vixen! /On, Comet! On, Cupid! On, Donner and Blitzen!/To the top of the porch! To the top of the wall! /Now dash away! Dash away! Dash away all! Our signer, instead, uses frequent repetition, a gratifying finding given that repetition helps with language development; the first time a language unit is used, the child can note it, but on later times, the child is primed to mimic (CORRIGAN, 1980). Repetition can be of many types: semantic units, phonetic ones, whole signs, and entire sequences (SUTTONSPENCE, \& KANEKO, 2016).

With respect to semantic units, the single line The stockings were hung by the chimney with care is rendered by a long clip (0:29-0:46). The signer tells us to take a close look, and we'll see that the house is decorated. He introduces the mantelpiece (0:36), indicating loops 
there - three, in fact $(0: 37-0: 39)$. He tells of red (0:40) stockings - three, again (0:41-0:42) with white $(0: 43)$ cuffs on top $(0: 44-0: 46)$. The three loops set us up for the three stockings, which sets us up for the three cuffs. In each case the first, second, and third instance of a sign is given in consecutive location points along a spatial line, moving from signer's left to right. The reader is primed by the first instance to mimic the second and third.

We find this same repetition of three's in the clip corresponding to the text line The children were nestled all snug in their beds (0:55-1:04). Here we are told about three beds with a child in each, again along that spatial line from left to right. And three's come up in the video corresponding to the text line: While visions of sugar-plums danced in their heads (1:05-1:15).

The signer introduces CANDY(1:07), followed by pointing at three spots high in the air (1:08), COOKIES (1:09), followed by pointing to those spots again (1:10), and finally SUGAR P-L-U-M$S^{2}(1: 11-1: 12)$, followed by pointing to the spots $(1: 13)$. So there are three similar objects, with three pointings in space after each. This instance of threes introduces information not in the text or the illustrations (candy and cookies) in order to do important vocabulary work. Candy and cookies are familiar sweets. But sugar plums are unfamiliar. The signer deftly teaches the child what sugar plums are without being pedantic. This inferential learning is implicit at the particular level (two sweets - followed by a third item, so it must also be a sweet) and at the general level (two similar things - followed by an unknown, so it must be similar to the others).

Groups of three are likewise repeated in the clip already cited above, 4:33-4:44, as we see Santa fill each of the stockings hanging from the chimney.

Phonetic repetitions occur often in the signed story, as do full sign repetitions, including ALL-AROUND (0:16 and 0:57), HOUSE (0:15, 0:56, 2:38), FAMILY (0:32 and 0:58). Sometimes the signer marks clips as semantically parallel by ending them with the same sign. Of the four clips corresponding to the four lines below, all but the third ends with the sign FALL-ASLEEP:

0:55-1:04 The children were nestled all snug in their beds

1:05-1:15 while visions of sugar plums danced in their heads

1:16-1:22 And Mama in her 'kerchief, and I in my cap

1:23-1:30 had just settled our brains for a long winter's nap

\footnotetext{
${ }^{2}$ We adopt the usual convention of using hyphens between letters to indicate fingerspelling.
} 
But the most striking repetition is of sequences. The signer often reminds us he is Santa, and he drives reindeers (1:55-1:57, 2:02-2:04, 2:12-2:13, 2:34-2:35, 5:06-5:07). The story ends perfectly with Santa driving that sleigh a final time (one quick move and a hold in 5:20).

\section{Transparency of literary techniques}

Sophisticated literary techniques can become transparent in signing. Much of signing involves iconicity (PERNISS, THOMPSON, \& VIGLIOCCO, 2010), analogy (SUTTONSPENCE, \& NAPOLI, 2013), and metaphor (TAUB, 2001), and the signing in this ebook is no exception. A text simile is rendered by a sign simile with explicit LIKE in the second clip here:

3:55-4:00 The stump of $a$ pipe he held tight in his teeth,
and the smoke it encircled .....
4:01-4:07 ...........................his head like a wreath.
....MY ALL-AROUND-FACE EDGES-OF-HEAD LIKE CHRISTMAS W-R-E-A-T-H

We see another text simile handled by simple sign juxtaposition (perhaps a metaphor) in: and the beard on his chin was as white as the snow (3:51-3:54).

The signer introduces a graphic metaphor in the clip corresponding to this line: The children were nestled all snug in their beds, (0:55-1:04). We see the children in bed, then the signer tightens his fingers around the last child (1:02), as a metaphor for snugness. Our signer is clearly helping the child become comfortable with similes and metaphors.

\section{Attention as a key to literacy.}

In order for these techniques to work, the child must pay attention. Eyegaze is important here. Further, one might expect child-directed signing to play a role. But while our signer uses eyegaze instructively, he does not use child-directed sign.

Eyegaze. Joint attention is defined as an observer following the eyegaze of an interactant to a target (CORKUM, \& MOORE, 1995). It is important for a successful SRA, particularly for deaf children (SWANWICK, \& WATSON, 2007) or children with language-related special needs (KADERAVEK, \&JUSTICE, 2002). Discussions of joint attention usually concern live 
interactions. However, addressees visually attend to a video narrator's gestures if the narrator holds a gesture or gazes at her own gesture (GULLBERG, \& HOLMQVIST, 2006). Also, deaf preschoolers learn ASL from 'interacting' with a screen character (HUANG, et al., 2008), and show improved literacy-related engagement behaviors after watching educational sign videos (GOLOS, 2010), both of which results presume joint attention. At least six types of eyegaze identified in sign literature (KANEKO, \& MESCH, 2013) potentially foster/scaffold joint attention, and allare used by our signers:

(1) narrator's gaze at the audience. Our signer opens with this and uses it often.

(2) character's gaze. An example is when Santa looks around the house (0:57).

(3) spotlight gaze on hand(s). The signer alternates between narrator's and spotlight gaze as he describes the stockings (0:29-0:46).

(4) reactive gaze on hands, showing how the signer feels toward what the hands tell. This is in the two clips about what the narrator sees when he opens the window (1:39-1:47) and discovers a miniature sleight and eight reindeers (1:48-1:57 - the reactive gaze ends at 1:55).

(5) panoptic gaze, where the eyes add information to manual signs. When the narrator hears hoof beats on the roof, his eyes go upward and right, indicating the sound's source (3:01).

(6) prescient gaze, indicating future action by anticipatory looking. We find it in the clip corresponding to And away they all flew like the down of a thistle (5:00-5:04). At the end, the signer raises his eyes, and at the beginning of the next clip, he rides off in his sleigh.

Thus the signer's eyes establish joint attention by looking directly at the camera, inviting the reader to return direct gaze, and by looking at a target, pulling the reader's eyes toward it.

Child-directed signing. Some have argued that child-directed speech (with exaggerated prosody) helps small children learn words (mean age of 30 months; see GOLINKOFF, et al., 1992). Further, exaggerated pitch differences in child-directed speech help preschoolers interpret others' emotions (QUAM, \& SWINGLEY, 2012). So we might expect child-directed signing (again, studied mostly with respect to preschoolers) during SRAs to help children gain vocabulary and better understand characters' emotions in stories.

Child-directed signing by deaf parents uses larger, slower, more repetitious signing (that is, with lexical-internal repetition), as well as signing on the child's body or displacement of signs to within the child's visual field (HOLZRICHTER, \& MEIER, 2000) - all of which help direct the child's attention to the language act. In this ebook many signs are large and slow. 
However, the size and rate of signing correspond to narrative structure, not visual salience of individual signs. In general, our signer places verbs toward the end of a clip, and often they are larger and slower. But nothing about his signing suggests it is child-directed, not the type of repetitions nor the lexical items used (and see HOLZRICHTER,\& MEIER, 2000).Instead, our signer helps develop vocabulary by using signs in isolation or in brief utterances as well as stressing signs (by lengthened duration and increased size (DE TEMPLE, \& SNOW, 2003, p. 18). But he keeps in mind pleasure for both child and adult; on an adult reader, child-directed language soon wears thin.

So the lack of child-directed language was an aesthetic judgment on our signer's part. These ebooks are not intended for the child to use alone (although they can be). They are intended for child and adult together, so they must attract both. Only then will both eagerly reach for them, and only then will we find the kind of language interaction we seek to encourage.

\section{Use of the ebooks at home and at school}

Thus far, we have underscored the child's enjoyment and shown through examination of one of our ebook show they offer help in implicit development of sign literacy skills and preparation for print literacy skills. But what is the role of the adult in the SRA? Many continue to propose that hearing parents need to be taught how to engage with their deaf children in SRAs, even SRAs that use bimodal-bilingual ebooks (DIRKS, \& WAUTERS, 2015). We repeat our reasons for being skeptical: following guidelines may result in joyless lessons which stress the adult, and, hence, the child. If both parent and child are to want to repeat SRAs, both must enjoy it. We've selected the source books for our ebooks with both parent and child in mind. And our signers use signing that should be pleasing to both child and adult (they have avoided childdirected signing).

We suggest, then, that parent and child can share these ebooks in whatever way they want. The parent might simply read the text while the child looks at the videos. The parent might point to illustrations and try to guess what part of the signing is describing the visuals that the illustrations are providing (such as the children snug in bed in the Santa story) and then ask the child to make further guesses (perhaps about the loops of decorations on the mantelpiece). The parent might imitate the actions in the story - acting them out like a mime - and invite the child to do the same. The parent could copy the signer and encourage the child to do the same. 
As signing knowledge grows, the parent and child could have conversations in sign about the story, and then about what's going to happen in their home on the next holiday, and then about whatever else they want.

That is, interaction may be minimal or it may be prolonged and complex. So long as both parent and child are enjoying themselves, repeated sharings of the ebooks will almost assuredly result in improved signing skills for both, and in increased language interaction over the books, which cannot help but develop better understanding of narrative and characterization. That is, we hope that these unscripted and joyful SRAs will be as fruitful for the emergent deaf reader as unscripted and joyful SRAs are for the emergent hearing reader. And at the very least, parent and child will have fun together. Teachers of deaf children can help parents of deaf children by recommending these SRAs, and explicitly telling parents that there is no one right way to use them. They can give parents license to simply enjoy sharing a story with their child instead of constantly worrying about what their child is learning.

Likewise, these ebooks can be shared in classrooms. While everyone knows that preschoolers need SRAs (even pediatricians recommend them; DUURSMA, AUGUSTYN, \& ZUCKERMAN, 2008), elementary school children do, as well (GAMBRELL, 2011). The classroom teacher must find the time in the school day to simply read with the children for pure pleasure. These ebooks offer that, with the superb side benefits of exposure to a sign language and another culture, and the opportunity to discuss Deaf Culture and variations within the deaf community.

The ebooks can be shared the same way ordinary picture books are shared - at 'circle time', not just by teachers who have been trained to work with deaf children, but by any teacher, with any set of children. Deaf and hearing children, alike, can enjoy the signing, simply watching it and talking about what they see. They can note the different shapes the hands can assume, the space the hands move around in, the ways the different parts of the face move. They can be encouraged to make up signs for objects that lend themselves to transparent visual representations - like 'book', 'glass', 'tree', 'house' - then the teacher can look up the real signs in an online dictionary and the whole class can compare their made up signs to the real signs. They can have fun imagining occasions in which it would be a huge benefit to be able to communicate with someone silently. If there's strong interest in a particular story, a follow-up activity might be acting out that story and, gradually, moving more and more toward signing it. 
Deaf and hearing children can be encouraged to check out the books for sharing at home and can be challenged with learning to sign a page or more or with explaining the signing to their parents. Table 1 outlines some of the ways the ebooks can support a mainstreamed classroom.

Table 1 - Strategies for Using Bilingual-Bimodal Ebooks in the Classroom

\begin{tabular}{|c|c|}
\hline Introducing a new topic: & $\begin{array}{l}\text { Literature that relates thematically to a lesson can serve to } \\
\text { acquaint a deaf student with the topic at hand. }\end{array}$ \\
\hline Supporting deaf identity: & $\begin{array}{l}\text { The deaf child who learns to sign the story in an ebook can } \\
\text { teach the whole class, showing that ASL is a real language. }\end{array}$ \\
\hline $\begin{array}{l}\text { Supporting independent } \\
\text { reading: }\end{array}$ & $\begin{array}{l}\text { Literature in sign might soothe feelings of frustration and } \\
\text { fatigue common among deaf children in a hearing environment. }\end{array}$ \\
\hline $\begin{array}{l}\text { Supporting the deaf child who } \\
\text { has vocalization skills: }\end{array}$ & $\begin{array}{l}\text { The ebooks have a voiceover. So those children who would } \\
\text { like to practice their speech skills can benefit. }\end{array}$ \\
\hline Using sign version as preview: & $\begin{array}{l}\text { Deaf students can read the ebook on their own (perhaps at } \\
\text { home) ahead of circle time in order to understand its content. }\end{array}$ \\
\hline Using sign version as review: & $\begin{array}{l}\text { After a book has been shared in circle time, deaf students can } \\
\text { read it on their own to further their understanding. }\end{array}$ \\
\hline $\begin{array}{l}\text { Comparing sign and text } \\
\text { versions for self-assessment: }\end{array}$ & $\begin{array}{l}\text { All students can find out how much English or ASL they are } \\
\text { learning by counting the words and signs they understand } \\
\text { before and after the book is shared in circle time. }\end{array}$ \\
\hline Learning about iconicity: & $\begin{array}{l}\text { All students can make up signs for things and then compare } \\
\text { them to the real signs in the stories. }\end{array}$ \\
\hline $\begin{array}{l}\text { Improving home-school } \\
\text { connections : }\end{array}$ & $\begin{array}{l}\text { Ebooks allow deaf family members active involvement in their } \\
\text { child's education, whether the child is deaf or hearing, even if } \\
\text { their English skills are limited. Deaf parents can be invited to } \\
\text { class to sign with the children. Weekend workshops on signing } \\
\text { might be made available, with transportation costs covered by } \\
\text { the school. }\end{array}$ \\
\hline $\begin{array}{l}\text { Supporting family literacy } \\
\text { programs: }\end{array}$ & $\begin{array}{l}\text { Assisting parents of deaf students in locating ebooks is a great } \\
\text { way to start a family literacy program. }\end{array}$ \\
\hline $\begin{array}{l}\text { Raising awareness of } \\
\text { multiculturalism: }\end{array}$ & $\begin{array}{l}\text { Ebooks can raise all children's awareness through exposure to } \\
\text { different languages and cultures. }\end{array}$ \\
\hline $\begin{array}{l}\text { Helping teachers and students } \\
\text { learn another language: }\end{array}$ & $\begin{array}{l}\text { Ebooks can help teachers and all children learn some sign. All } \\
\text { children can be encouraged to bring the ebooks home to share } \\
\text { with their families, so the children can practice signing at home. }\end{array}$ \\
\hline
\end{tabular}


Encouraging reading for pleasure:

Supporting students with other language-related issues
Our ebooks involve no stress. No one should be 'tested' on them. They are purely for fun.

Ebooks offer an augmentative communication system for children who have language-related issues, such as autism.

\section{Conclusion}

Our signers naturally employ techniques that make it easy for readers to understand, mimic, and retell stories in their own way. When we tested the ebooks at schools for the deaf, in fall 2013 and 2014, we found several behaviors among the children.

(1) They mimic the videos as they watch them repeatedly, even as of the second viewing.

(2) In retelling, they vary the stories, exaggerating to show feelings or personal interests.

(3) They tell the child next to them what the story is about, preparing them for it.

(4) They retell the ebooks together, as a game; one will elaborate on the other's sentence.

(5) Throughout these behaviors they use higher level facilitative language techniques (such as asking open-ended questions and building off each other's elaborations of the story).

These five characteristics are typical of effective SRAs (WHITEHURST, \& ZEVENBERGEN, 2003). Additionally, we found the following two behaviors:

(6) They play with signs and transform them, claiming language ownership (BAHAN, 2006).

(7) They appropriate the ebooks; they do not want teachers to explain them. Instead, they explain them to teachers. They are delighted these ebooks belong to them, as deaf people. Their teachers also love the videos, and are happy to see the children in discussion about stories.

We also tested the ebooks in homes in fall 2014. Children and parents were eager to share them repeatedly, except one group: hearing parents of deaf children. They were of the mindset that signing was not needed; their children had cochlear implants and were preschoolers; the parents were not (yet) discouraged about their likelihood of academic success with speech 
only. We also suspect they had been discouraged by medical professionals from signing with their children - a common experience (HUMPHRIES et al., 2012), and one we hope will change in the wake of a Pediatrics article recommending signing for all deaf children (NAPOLI, et al., 2015).

While we have applied for funding for a longitudinal study, our preliminary results are so promising, we hope others will not wait for formal results but use our ebooks now. We urge those involved in educating small deaf children to turn the focus toward fun. Parents look to teachers for guidance. Please encourage them to play with the ebooks and enjoy SRAs with their children. Deaf children certainly need pedagogical ebooks, but they also need ebooks that are simply fun; deaf children and their parents have a right to such an anxiety-free experience. More information about our ebooks can be found in this site:

http://www.gallaudet.edu/american_sign_language_and_deaf_studies/bilingual_ebooks.html

\title{
Resumo
}

Os e-books oferecem novas formas de desenvolver o letramento entre as crianças surdas. Enquanto alguns objetivam promover o letramento por meio de técnicas pedagógicas, os novos e-books, aqui descritos, têm como objetivo oferecer apenas histórias divertidas para serem compartilhadas, encorajando a aprendizagem por meio da interação, que naturalmente estimula habilidades da linguagem, dando início ao letramento de crianças surdas. Apresentamos a proposta destes e-books e damos exemplos de como eles promovem habilidades para o letramento, no sentido de criar e educar as crianças surdas para o uso desses materiais, oferecidos gratuitamente na internet.

Palavras-chave: crianças surdas, letramento, e-books, atividades de leitura compartilhada.

\begin{abstract}
Resumen
Los libros electrónicos ofrecen formas nuevas de desarrollar el letramento entre los niños sordos. Mientras algunos tienen el objetivo de promover el letramento a través de técnicas pedagógicas, los nuevos libros electrónicos, aquí descritos, tienen el objetivo de ofrecer solamente cuentos divertidos para ser compartidos, incentivando el aprendizaje a través de la interacción, acción que naturalmente estimulará las habilidades del lenguaje, iniciando el letramento entre niños sordos. Presentamos una propuesta para esos libros electrónicos y damos ejemplos de cómo ellos promueven las habilidades de letramento, en el sentido de criar y educar a los niños sordos para el uso de materiales, ofrecidos gratuitamente en internet.
\end{abstract}

Palabras-clave: niños sordos, letramento, libros electrónicos, actividades de lectura compartida. 


\section{References}

ALEXANDER, S.A., FROHLICH, K.L, \&FUSCO, C. 'Active play may be lots of fun, but it's certainly not frivolous': the emergence of active play as a health practice in Canadian public health. Sociology of Health \& Illness 36, 2014. p. 1188-1204.

ANDERSON, R.C., HIEBERT, E.H., SCOTT, J.A., \&WILKINSON, I.A.G. Becoming a nation of readers: the report of the Commission on Reading, U. S. Department of Education.

Champaign-Urbana, IL: Center for the Study of Reading, 1985.

BAHAN, B. Face-to-face tradition in the American deaf community. In: Bauman, H-D., Rose, H., \& Nelson, J. (eds.). Signing the body poetic, p. 21-50. Berkeley: University of California Press. 2006.

BASCOM, W. Four functions of folklore. In: Dundes, A. (ed.).The study of folklore, p. 279298. Englewood Cliffs: Prentice-Hall, 1965.

BASHA, T. Signed language proficiency and writing skill of deaf children in special and integrated primary schools in Addis Ababa.Turkish International Journal of Special Education and Guidance \& Counselling (TIJSEG) ISSN: 1300-7432 3,2014. p. 1-48.

BECK, S., \& OLAH, L. Perspectives on language and literacy: beyond the here and now. New York: Harvard Educational Review Reprint Series No. 35, 2001.

BIALOSTOK, S. Raising readers: helping your child to literacy. Winnepeg:Peguis Publishers Limited, 1992.

BLONDEL, M., \& MILLER, C. Rhythmic structures in French Sign Language (LSF) nursery rhymes. Sign Language and Linguistics, 3, 2000. p. 59-77.

BLONDEL, M., \&MILLER, C. Movement and rhythm in nursery rhymes in LSF. Sign Language Studies, 2, 2001. p. 24-61.

CALDERON, R. (2000). Parental involvement in deaf children's education programs as a predictor of child's language, early-reading, and social-emotional development. Journal of Deaf Studies and Deaf Education, 5, 2000. p. 140-155. doi: 10.1093/deafed/5.2.140

CHALHOUB-DEVILLE, M. Second language interaction: current perspectives and future trends. Language Testing, 20, 2003. p. 369-383.

CHAMBERS, C.G., TANENHAUS, M.K., EBERHARD, K.M., FILIP, H., \&CARLSON, G.N. Circumscribing referential domains during real-time language comprehension. Journal of Memory and Language, 47, 2002. p. 30-49. 
CORRIGAN, R. Use of repetition to facilitate spontaneous language acquisition. Journal of Psycholinguistic Research, 9, 1980. p. 231-241.

CORKUM, V., \&MOORE, C. Development of joint visual attention in infants. In: Moore, C., \&Philip J.D. (eds). Joint attention: its origins and role in development, p. 61-83. Hillsdale, NJ: Lawrence Erlbaum Associates, Inc., 1995.

DE TEMPLE, J., \&SNOW, C.E. Learning words from books. In: Van Kleeck, A., Stahl, S.A., \& Bauer, E.B. (eds.). On reading books to children: parents and teachers, p. 16-36. East Sussex, UK: Psychology Press, 2003.

DECKNER, D., ADAMSON, L., \&BAKEMAN, R. Child and maternal contributions to shared reading: effects on language and literacy development. Journal of Applied Developmental Psychology, 27,2006. p. 31-41.

DENNIS, L.R., LYNCH, S.A., \& STOCKALL, N. Planning literacy environments for diverse preschoolers. Young Exceptional Children,15, 2012. DOI:1096250612437745.

DICKINSON, D., MCCABE, A., \& ESSEX, M. A window of opportunity we must open to all: The case for preschool with high-quality support for language and literacy. In: Dickinson, D., \&Neuman, S. (eds.). Handbook of early literacy research: Volume 2, p. 11-28. New York: The Guilford Press, 2006.

DIRKS, E., \& WAUTERS, L. Enhancing emergent literacy in preschool deaf and hard-ofhearing children through interactive reading. In: Knoors, H., \&Marschark, M. (eds.).Educating deaf learners: creating a global evidence base, p. 415-442. New York: Oxford University Press, 2015.

DUURSMA, E. V., AUGUSTYN, M., \& ZUCKERMAN, B. Reading aloud to children: the evidence. Archives of Disease in Childhood, 93, 2008. p. 554-557.

EASTERBROOKS, S.R., LEDERBERG, A.R., ANTIA, S., SCHICK, B., KUSHALNAGAR, P., WEBB, M.Y., BRANUM-MARTIN, L., \& CONNOR, C.M. Reading among diverse DHH learners: what, how, and for whom? American Annals of the Deaf 159. 2015. p. 419-432.

EDWARDS, V., MONAGHAN, F., \& KNIGHT, J. Books, pictures and conversations: using bilingual multimedia storybooks to develop language awareness. Language Awareness, 9, 2000. p. 135-146.

EDMISTON, B. Forming ethical identities in early childhood play. New York: Routledge, 2007.

EWOLDT, C. What does 'reading', mean? Perspectives for Teachers of the Hearing Impaired, 4, 1986. p. 10-13. 
FREEL, B., CLARK, M., ANDERSON, M., GILBERT, G., MUSYOKA, M., \&HAUSER, P. Deaf individuals' bilingual abilities: American Sign Language proficiency, reading skills, and family characteristics. Psychology, 2, 2011. p. 18-23.

FUNG, P.C., CHOW, B.W.Y., \& MCBRIDE-CHANG, C.The impact of a dialogic reading program on deaf and hard-of-hearing kindergarten and early primary school-aged students in Hong Kong. Journal of Deaf Studies and Deaf Education, 10, 2005. p. 82-95.

GAMBRELL, L.B. Seven rules of engagement: What's most important to know about motivation to read. The Reading Teacher, 65, 2011. p. 172-178.

GELLER, L.G. Children's rhymes and literacy learning: making connections. Language Arts, 60,1983, p. 184-193.

GOLINKOFF, R. M., HIRSH-PASEK, K., BAILEY, L.M., \&WENGER, N.R. Young children and adults use lexical principles to learn new nouns. Developmental Psychology, 28, 1992, p. 99-108.

GOLOS, D. Literacy behaviors of deaf preschoolers during video viewing. Sign Language Studies, 11, 2010. p. 76-99.

GREENE BRABHAM, E., \&LYNCH-BROWN, C. Effects of teachers' reading-aloud styles on vocabulary acquisition and comprehension of students in the early elementary grades. Journal of Educational Psychology, 94,2002. p. 465-473.

GUAÏTELLA, I. Rhythm in speech: what rhythmic organizations reveal about cognitive processes in spontaneous speech production versus reading aloud. Journal of Pragmatics, 31, 1999. p. 509-523.

GULLBERG, M., \& HOLMQVIST, K. What speakers do and what addressees look at: visual attention to gestures in human interaction live and on video. Pragmatics \& Cognition, 14, 2006.p. 53-82.

HASSANZADEH, S. Outcomes of cochlear implantation in deaf children of deaf parents: comparative study. Journal of Laryngology and Otology, 126, 2012.p. 989-994.

HOLZRICHTER, A.S., \&MEIER, R.P. Child-directed signing in American Sign Language. In: Chamberlain, C., Morford, J., \& Mayberry, R. (eds.). Language acquisition by eye, p. 2540.Mahway, NJ: Lawrence Erlbaum Associates, Inc., 2000.

HUANG, K., SMITH, J., SPREEN, K., \& JONES, M.F. Breaking the sound barrier: designing an interactive tool for language acquisition in preschool deaf children. In: Cassell, J. (conference chair). Proceedings of the 7th international conference on interaction design and children, p. 210-216. New York: ACM Digital Library, 2008. 
HUMPHRIES, T., KUSHALNAGAR, P., MATHUR, G., NAPOLI, D.J., PADDEN, C., RATHMANN, C., \& SMITH, S. Language acquisition for deaf children: reducing the harms of zero tolerance to the use of alternative approaches. Harm Reduction Journal, 9:16, 2012. Available at: http://www.harmreductionjournal.com/content/9/1/16.

HUSS, M., VERNEY, J.P., FOSKER, T., MEAD, N., \& GOSWAMI, U. Music, rhythm, rise time perception and developmental dyslexia: perception of musical meter predicts reading and phonology. Cortex, 47,2011. p. 674-689.

KADERAVEK, J., \&JUSTICE, L.M. Shared storybook reading as an intervention: context, practices and potential pitfalls. American Journal of Speech-Language Pathology, 11,2002. p. 395-406.

KALIA, V. Assessing the role of book reading practices in Indian bilingual children's

English language and literacy development. Early Childhood Education Journal, 35,2007. p. 149-153.

KANEKO, M. Alliteration in sign language poetry. In: Roper, J. (ed.). Alliteration in culture, p. 231-46.Basingstoke: Palgrave MacMillan, 2011.

KANEKO, M., \&MESCH, J. Eye gaze in creative sign language. Sign Language Studies, 13, 2013. p. 372-400.

KRENTZ, C. The camera as printing press: how film has influenced ASL literature. In: Bauman, H-D., Rose, H., \& Nelson, J. (eds.). Signing the body poetic, p. 51-70. Berkeley: University of California Press, 2006.

KUSCHNER, D., Ed. From children to red hatters: diverse images and issues of play. Landham, MD: University Press of America, 2008.

LEDERBERG, A., SCHICK, B., \&SPENCER, P.(2013). Language and literacy development of deaf and hard-of-hearing children: successes and challenges. Developmental Psychology, 49, 2013. p. 15-30.

MALER, A. Songs for hands: Analyzing interactions of sign language and music. Music Theory Online 19, 2013. Accessed 20 July 2016. http://www.mtosmt.org/issues/mto.13.19.1/mto.13.19.1.maler.html\#kaneko_2011

MARTIN, P.Making happy people: the nature of happiness and its origins in childhood. London: Harper Collins UK, 2014.

MAYBERRY, R.I., DEL GIUDICE, A.A., \& LIEBERMAN, A.M. Reading achievement in relation to phonological coding and awareness in deaf readers: a meta-analysis. Journal of Deaf Studies and Deaf Education 16,2011. p. 164-188. 
MAYER, C., \&TREZEK, B.J. Early literacy development in deaf children. Oxford: Oxford University Press, 2015.

MAYER, C., \& WELLS, G. Can the linguistic interdependence theory support a bilingual model of literacy education for deaf students? Journal of Deaf Studies and Deaf Education, 1, 1996. p. 93-107.

MOL, S.E., \& BUS, A.G. To read or not to read: a meta-analysis of print exposure from infancy to early adulthood. Psychological Bulletin, 137, 2011. p. 267-296.

MOORE, M., \& WADE, B. Reading strategies: a comparative study of ex-Reading Recovery students and peers. Research in Education, 60,1998. p. 21-28.

MOUNTY, J.L., PUCCI, C.T., \& HARMON, K.C. How deaf American Sign Language/ English bilingual children become proficient readers: an emic perspective. Journal of Deaf Studies and Deaf Education, 19, 2014. p. 333-346.

MUELLER, V., \& HURTIG, R. Technology-enhanced shared reading with deaf and hardof-hearing children: the role of a fluent signing narrator. Journal of Deaf Studies and Deaf Education, 15, 2010.p. 72-101.

MURAYAMA, K., PEKRUN, R., LICHTENFELD, S., \&VOM HOFE, R. Predicting long-term growth in students' mathematics achievement: the unique contributions of motivation and cognitive strategies. Child Development, 84,2013.p.1475-1490.

NAPOLI, D.J., \& MIRUS, G. Shared reading activities: a recommendation for deaf children. Global Journal of Special Education and Services, 3, 2015. p. 38-42.

NAPOLI, D.J., MELLON, N.K., NIPARKO, J.K., RATHMANN, C., MATHUR, G., HUMPHRIES, T., HANDLEY, T., SCRAMBLER, S.,\& LANTOS, J.D. Should all deaf children learn sign language? Pediatrics, 136, 2015. p. 170-176.

PERNISS, P., THOMPSON, R., \& VIGLIOCCO, G. Iconicity as a general property of language: evidence from spoken and signed languages. Language Sciences, 1,2010. p. 227243.

PETERS, S.M. LENA Measurements of language facilitation strategies utilized by parents during storybook reading, 2015.(MA thesis). Utah State University in Logan, UT.

QUAM, C., \& SWINGLEY, D. Development in children's interpretation of pitch cues to emotions. Child Development, 83, 2012. p. 236-250.

RIGGS, T. Visual vernacular: storytelling in ASL. East Bend, NC: Signs of Development, 2003. 
RYAN, S.M. 'Let's tell an ASL story.' In: Gallaudet University College for Continuing Education (org.). Conference Proceedings, April 22-25, 1993, p. 14-47. Washington, DC: Gallaudet University Press, 1993.

SCHICK, B., DE VILLIERS, P., DE VILLIERS, J., \& HOFFMEISTER, R. Language and theory of mind: a study of deaf children. Child Development, 78, 2007. p. 376-396.

SCHLEPER, D.R. Reading to deaf children: learning from deaf adults. Perspectives in Education and Deafness, 13, 1995. p. 4-8.

SCOTT, J. A. Beyond the fourth grade glass ceiling: understanding reading comprehension among bilingual/bimodal deaf and hard of hearing students. 2015. (Doctoral dissertation). Graduate School of Education, Harvard University.

SEMINGSON, P., POLE, K., \& TOMMERDAHL, J. Using bilingual books to enhance literacy around the world. European Scientific Journal,11, 2015. p. 132-139.

SKOUGE, J.R., RAO, K., \& BOISVERT, P.C. Promoting early literacy for diverse learners using audio and video technology. Early Childhood Education Journal, 35, 2007. p. 5-11.

STOKOE, W. C. JR. Sign language structure: an outline of the visual communication systems of the American Deaf. Studies in Linguistics: Occasional Papers No. 8. Buffalo, NY: University of Buffalo, 1960.

SUTTON-SPENCE, R., \&KANEKO, M. Introducing sign language literature: creativity and folklore.London: Palgrave Press, 2016.

SUTTON-SPENCE, R., \&NAPOLI, D.J. How much can classifiers be analogous to their referents? Gesture, 13, 2013. p. 1-27.

SWANWICK, R., \& WATSON, L. Literacy in the homes of young deaf children: common and distinct features of spoken language and sign bilingual environments. Journal of Early Childhood Literacy, 5, 2005. p. 53-78.

SWANWICK, R., \&WATSON, L.Parents sharing books with young deaf children in spoken English and in BSL: the common and diverse features of different language settings. Journal of Deaf Studies and Deaf Education,12,2007. p. 385-405.

TANENHAUS, M.K., SPIVEY-KNOWLTON, M.J., EBERHARD, K.M., \& SEDIVY, J.C. Integration of visual and linguistic information in spoken language comprehension. Science, 268,1995. p. 1632-1634.

TAUB, S.F. Language from the body: iconicity and metaphor in American Sign Language. Cambridge: Cambridge University Press, 2001. 
TRIVETTE, C. M., DUNST, C. J., \& GORMAN, E. Effects of parent-mediated joint book reading on the early language development of toddlers and preschoolers.Center for Early Literacy Learning, 3,2010. p. 1-15.

VALLI, C. Poetics of American Sign Language poetry, 1993.(doctoral dissertation). The Union Institute Graduate School.

VAN KLEECK, A. Providing preschool foundations for later reading comprehension: the importance of and ideas for targeting inferencing in storybook-sharing interventions. Psychology in the Schools, 45, 2008. p. 627-643.

WATSON, R. Literacy and oral language: implications for early literacy acquisition. In:Neuman, S. \&Dickinson, D. (eds.). Handbook of early literacy research: Volume 1, p. 43-53. New York: The Guilford Press, 2001.

WHITEHURST, G.J., \& LONIGAN, C.J. Child development and emergent literacy. Child Development, 68,1998. p. 848-872.

WHITEHURST, G.J., \& LONIGAN, C.J. Emergent literacy: development from prereaders to readers. In: Neuman, S. \& Dickinson, D. (eds.). Handbook of early literacy research: Volume 1,p. 11-29. New York: The Guilford Press, 2001.

WHITEHURST, G., \&ZEVENBERGEN, A. Dialogic reading: a shared picture book reading intervention for preschoolers. In: Van Kleeck, A., Stahl, S A., \& Bauer, E.B. (eds.). On reading books to children: parents and teachers, p. 177-200. East Sussex, UK: Psychology Press, 2003.

WILLIAMS, C. Emergent literacy of deaf children. Journal of Deaf studies and Deaf Education, 9, 2004. p. 352-365.

WILLINGHAM, D.T. Raising kids who read: what parents and teachers can do.San Francisco: Jossey-Bass/Wiley, 2015. 